\title{
Mitigating the Risk of Fraud in Documentary Letters of Credit
}

\author{
Hamed Alavi \\ Tallinn Law School, \\ Tallinn University of Technology \\ Akadeemia tee 3 , \\ Tallinn 12618, Estonia \\ E-mail: hamed.alavi@ttu.ee
}

Abstract: Despite the fact that documentary letters of credit (LC) are meant to facilitate the process of international trade, their specific characteristics may increase the risk of fraud while being used as the method of payment in the process of international transaction. Many factors like exclusive use of documents, geographical distance, absence of efficient prosecution, the diversity of legal system at the global level and restricted application of fraud rule can be considered as reasons for LC fraud. While billions of dollars are lost annually due to fraud in the course of LC operations, such vulnerability can result in reducing the global popularity of documentary letters of credit as the main method of payment used in international trade. Meanwhile, it is worth mentioning that fraud risk management is an unexplored territory in the practice of documentary letters of credit operation. Existing research tries to fill the gap in the study on comprehensive methods for mitigating fraud risk in operations with documentary letters of credit by using risk management theory in order to answer the question of how to manage fraud risk in LC transactions? In a quest to answer the research question, the paper is divided into two parts: the first part is dedicated to preventive measures while the latter explores responsive measures of an enterprise to manage fraud risk in LC transactions.

Keywords: documentary letters of credit, fraud, international trade, risk management 


\section{Introduction}

Risk has been attributed to uncertainty (Crockford, 1980) and risk management in the business world is defined as managing the risks of an enterprise on the way to achieve its objectives (Monahan, 2008). In order to manage risk, it is necessary to have a proper understanding of factors contributing to risk, such as risk-driving controls, probable events which take place in the presence of risk and, finally, possible outcomes. The logical steps to manage an existing risk are: risk identification, risk measurement, risk evaluation and its re-evaluation (Hertz \& Howard, 1983, pp. 11-17). In addition, it is recommended to reduce the probability of the occurring risk via putting a ban on risky activities, reducing any activity which might result in a risk occurrence, and conducting a thorough analysis of all factors which contribute to the risky nature of the company's activities (Crouch \& Wison, 1982, pp. 195-201). As a result, researchers recommend applying risk management techniques as an integral part of business activities (Carey \& Turnbull, 2001).

In fact, fraud is one of the oldest and best-known phenomena in the business world. "As long as there have been commercial systems in place, there have been those who have tried to manipulate these systems" (ICC International Maritime Bureau, 2002). Due to the huge costs that fraud might impose on small and large enterprises, it has been argued by Spencer Pickett (2006) that it should be put at the center stage. However, evidence shows that many companies involved in international trade have failed to elaborate the risk of fraud in the framework of their enterprise risk management (ERM). Controversially, the risk of fraud and its potential cost for an enterprise will increase if a less serious attitude is taken towards it. The essential elements in a company which result in vulnerability to fraud risk are: weak controls, dishonest employees, lack of clarity regarding company resources and negligent managers. Fraudsters victimize companies which do not employ proper control measures and protect themselves from law enforcement bodies by finding legal loopholes in particular jurisdictions (ICC Commercial Crime Services, 2002). Especially companies active in international trade are advised to consider risk of fraud seriously and implement sound anti-fraud measures in order to reduce the possibility of being a fraud victim. In comparison to domestic trade, risk of fraud in international trade is much higher due to factors like the geographical distance between parties, the use of other methods of payment based on documents rather than cash or payment in advance, and the lack of efficient prosecution and diversity of legal systems. 
According to the American Institute of Certified Public Accountants (AICPA, 2009), a sound anti-fraud policy should adopt four main measures, including prevention, detection, deterrence and response. However, effective fraud risk management policy will be considered to be the one which can prevent the fraud and its costly consequences before its actualization. Since none of fraud preventive measures are fully accountable, it is necessary to include a response plan in the policy of fraud risk management by providing the employees proper instruction and information.

\section{Fraud in documentary letters of credit}

Documentary letters of credit, or LCs, are widely used in international trade as a means of financing and payment. Although they are supposed to facilitate the process of international trade by shifting the payment risk from the applicant buyer to the payment guarantee offered by the bank, the sole reliance of the bank on the presentation of complying documents with LC requirement and the absolute application of the principle of independence will make them vulnerable to the risk of fraud. The principle of independence of documentary credits separates the obligation of the issuing bank in making payment to the beneficiary from obligations of the beneficiary to the account party under the contract of sales. According to Article 5 of the Uniform Customs and Practice for Documentary Credits, UCP 600, "banks deal with documents not goods or services", which means that banks "deal with written presentation not fact" (Harfield, 1974, p. 69). Therefore, a beneficiary does not need to prove fulfilment of his obligation in an underlying contract and only presenting the complying documents will entitle him to receive a payment from the issuing bank. Fraud has been considered as the "most controversial and confused area" (Harvard Law Review, 1980) as it goes to the very heart of documentary credit by obliging the bank to look at the facts behind complying presentation and stop payment in cases of fraud in transaction" (Buckley \& Gao, 2002, p. 66). A report of the United Nations' Conference on Trade and Development (UNCTAD, 2009) considers buyers as victims of fraud in LC transactions, while defining four types of LC frauds as the most popular methods of defrauding account parties in international trade: the first is a falsification of documents by the beneficiary in order to obtain the payment from the issuing bank when no cargo exists in practice. The second is when the goods delivered by the beneficiary do not comply with the contract of sales in quantity and quality. The third is selling the same cargo to more than one person, and the fourth is issuing a document 
of title (bill of lading) twice for the same cargo. Additionally, banks have also been reported as frequent victims of fraud in LC transactions (Ellen, 1998, p. 1). According to an UNCTAD report, fraudsters fabricate patterns of international trade by heavy investments during a few years and then defraud bankers who are only focused on documents (UNCTAD, 2003).

Fraud in LC transactions is becoming more and more sophisticated and new fraud schemes are developed constantly (Mukundan, 2009). In this respect, there are two main problems which should be addressed. First, there is no internationally accepted legal regime for combating fraud risk in LC transactions and it is covered under national rules. ${ }^{1}$ Second, prevention of fraud in LC transactions has not been explored thoroughly by researchers. The increasing number of cases of fraud in international LC transactions has resulted in recognition of fraud rule as the first and foremost exception to the principle of independence of LCs. While on the one hand, there is no harmonious attitude towards fraud rule in different jurisdictions, on the other hand, the high number of legal cases will undermine the popularity of documentary letters of credit as a major tool in trade finance. Therefore, current research will try to use risk management theory for the purpose of reducing fraud risk in international LC transactions and seek answer to the question of which are best practices in mitigating the risk of fraud in international LC transaction.

\section{Grounds for fraud in international LC transaction}

Fraudsters might affect any of parties involved in international LC transactions. Despite the fact that in the majority of cases the applicant is considered a victim of fraudulent activities, development of new fraud schemes has resulted in an increasing number of legal cases with beneficiary and banks as fraud victims. Different discovered grounds for fraud in international LC transaction will be discussed as follows.

Unified Customs and Practices in Practice of Documentary Letters of Credit (currently, UCP 600) as the most internationally popular set of rules in LC operation takes an absolute silent position regarding fraud and the UNCITRAL Convention on Bank Gaurantees and Standby Credits does not cover commercial documentary letters of credit. 


\subsection{Defrauding applicant}

On the basis of an underlying international sales contract, the buyer applies for opening the credit in favor of the seller. The documentary nature of LC can be a good motivation to an ill-fated beneficiary to defraud the applicant by submission of conforming documents to the bank without fulfilling his commitments in the underlying sales contract and shipping goods to the buyer. Since it will take time for the ship to cover the distance between the port of departure and the port of destination, the applicant buyer will be informed about the forged nature of the documents tendered by the beneficiary to the bank long after credit negotiation (Godier, 2001). Other techniques for defrauding the applicant buyer have been explained in the UNCTAD 2003 Report (UNCTAD, 2003).

\subsection{Defrauding the issuing bank}

In the process of the documentary letter of credit's operation, the beneficiary seller should submit original negotiation documents of title either to the issuing bank in the applicant's country or to the confirming, negotiating, or advising bank in his own country. Meanwhile, the beneficiary will dispatch a non-negotiable set of documents of title to the applicant in order to advise him regarding name of ship and approximate date of its arrival at the port of destination. An ill-fated applicant can forge original documents of title on the basis of non-negotiable ones which has been received from the seller, present them to the carrier upon the arrival of the ship at the port of destination and receive a delivery order of releasing the goods while leaving the bank with a liability to make the payment to the beneficiary (Demir-Araz, 2002).

\subsection{Defrauding the confirming bank}

In the famous cases of Banco Santander S.A. v Bayfern Ltd [1999], the beneficiary negotiated complying documents of a deferred payment letter of credit to Banco Santander, which was the confirming bank in the abovementioned credit. Upon maturity of the credit, Banco Santander required a payment from the issuing bank, which was denied due to the submission of fraudulent documents. Decision of the court in the case of Banco Santander SA v Banque Paribas was in favor of the issuing bank and ruled that the issuing bank was right in withholding payment to the confirming bank. However, in the recent revision of UCP (UCP 600 , Art. 7C), the issuing bank is mandated to reimburse the confirming bank in case of honoring deferred credits before maturity. 


\subsection{Defrauding the insurance company}

Fraudulent parties can enter into contract of sales, ship no goods, scuttle the vessel on the way to the port of destination and claim damages from an insurance company. It is also possible to sell shipped goods to a third party and then scuttle the ship after redirecting it and claim damages from the insurance company (Demir-Araz, 2002).

\section{Fraud risk management in documentary letters of credit}

As it has already been discussed, effective fraud risk management strategy includes four main elements of prevention, detection, deterrence and response (AICPA, 2009). In the framework of documentary letters of credit, such effective anti-fraud strategy will be more relevant to prevention and response. The next segment of current research will focus on preventive anti-fraud strategies for different parties involved in operation of documentary letters of credit.

\subsection{Preventive measures for banks}

As it has been mentioned already, Article 5 of UCP 600 stipulates that in order to honor a credit, banks deal only with documents, not goods or services. In accordance with Article 5, Article 14(a) of UCP 600 on standards for examination of documents mentions that: "A nominated bank acting on its nomination, a confirming bank if any and the issuing bank must examine the presentation to determine, on the basis of documents alone, whether or not the documents appear to constitute a complying presentation". The emphasis of UCP 600 on separating credit from its underlying contact and limiting duty of bank to check the presentation of complying documents on their face follows the goal of facilitating the process of international trade and increasing the speed of cross-border transactions. On the other hand, it will result in the vulnerability of documentary letter of credit to fraudulent conduct of ill-fated beneficiaries. Altogether, limiting the duty of banks only to examine the presented documents on their face and taking an absolute silent position towards the risk of fraud in LC transactions has resulted in criticism of UCP 600 by many scholars. Shoia Lin Kuo comments on the necessity to extend the banks duty to check performance of beneficiary in fulfilling his promises in underlying contract rather than just dealing with documents in order to prevent fraud risk in international trade and operation of documentary letter of credits (Demir-Araz, 2002). Gao and 
Buckley (2002, p. 66) also raise the issue of a need to include the fraud rule in the next versions of UCP.

\subsubsection{Offer of "super service"}

Yanan Zhang (2012) recommends banks to offer a "super service" in order prevent the risk of fraud. Offering a bank "super service" to mitigate the risk of fraud in LC transactions was first proposed by UNCTAD in the 1980s (UNCTAD, 1983). Such a service entailed assuming responsibility of investigating the authenticity, accuracy and validity of presented documents by the beneficiary before undertaking payment. Offering a bank "super service" has received many criticisms, including the lack of capability for the bank to look behind documents and check their authenticity, existence of doubt about the effectiveness of "super service" to prevent fraud, high costs of providing such service, access of bank to sufficient communication networks in order to collect sufficient information about the authenticity of documents and signatures from agents, shippers, freight forwarders, buyers and sellers globally, and the existence of demand for such service.

As a result, offering such banking "super service" will have direct relations with customer demand and available resources for banks. Currently, some banks offer "super service" on optional basis.

\subsubsection{Further investigations}

Banks are generally affected by LC fraud in two ways. Either the bank's interests are threatened by a loss of defrauded applicant who will go bankrupt while not being able to reimburse the bank, or the applicant and the beneficiary collude together in order to defraud the bank (Todd, 1996). In both situations, the bank's interest is towards further investigation of the financial standing of the parties of the documentary LC as well as conducting individual investigations in nature transactions by their customers which might result in finding clues towards fraud or discovering discrepancies in documents presented by the beneficiary. However, such further investigations need time and sufficient qualified personnel, which, in practice, interprets as additional costs and less profit for the bank processing the LC transaction.

\subsubsection{More awareness in conducting daily business}

Banks are recommended to be prudent and aware in the course of conducting their daily business. The first step in increasing awareness among bank employees is offering fraud detective educational program (Liu, 2006, p. 21). Conducting proper check on the credibility of LC applicants is another measure which will 
increase the bank's awareness against fraudsters. Additionally, occasional check on documents presented by new clients, such as a random check of bill of lading presented by a less-known beneficiary, is recommended (Mukundan, 2008). Banks are also recommended to apply the fraud exception rule in the condition of receiving precise information about intention to conduct fraudulent claim before making payment to the beneficiary.

\subsubsection{Commercial crime service of the ICC}

The commercial crime division (CCS) of the International Chamber of Commerce (ICC) provides free service to its bank members (Islam \& Ahamed, 2008, p. 7). The issuing and confirming banks can always send complying documents presented by the beneficiary for authenticity check to the CCS. Since the CCS has access to databases of information from different parts of the world, asking it to perform an authenticity check on confirming documents presented to the bank will reduce the risk of fraud.

\subsection{Preventive measures for the applicant}

It has been constantly argued that the majority of LC fraud cases in the current status of international trade are targeted to the importer, buyer or applicant of documentary letter of credit. Therefore, it is worth studying fraud preventive measures which can be taken by the applicant in a comprehensive manner. As an accepted rule of thumb, preventive measures can be justified only in the case that their application will prevent higher expenses than their own costs. Therefore, the applicant is strongly advised to apply a thorough and comparative cost-benefit analysis before choosing any preventive measure to use. Having a complete picture about the expected costs of preventive measures can help an applicant make a rational decision as to which measure of combination of measures to choose. The most important preventive measures which can help an applicant to mitigate the risk of fraud in LC transaction are the following: studying the financial standing of the beneficiary, checking the location and condition of the contractual vehicle, employing independent inspectors, accepting time drafts instead of sight drafts, imposing the condition of "sales on approval" in the contract of sales, checking the authenticity of bill of lading, demanding carrier to dispatch the bill of lading to the bank, require performance guarantee, and use export credit insurance. 


\subsubsection{Checking the financial standing of the beneficiary}

The buyer is strongly recommended to conduct an extensive investigation on the financial standing of their business partner before entering into any contract with them (Xinqing, 2007). Applicants must consider that the existing cost of gathering information on credit-worthiness of their trade partner is much lower than a future loss as a result of being defrauded by an ill-fated beneficiary. Therefore, it will be beneficial for the applicant to bear costs of preliminary investigations in order to choose a trustworthy partner in international business transactions.

\subsubsection{Employing independent inspectors}

In the operation of documentary letters of credit, the bank will honor complying presentation only based on documents which are handed over by the beneficiary. This mode of operation might result in presenting complying documents by the seller without fully performing his obligations based on the underlying contract. In order to reduce the risk of payment based on forged documents or documents which incorrectly prove the fulfilment of the seller's obligation based on the underlying contract, applicants are advised to employ an independent inspector and insert in the contract the condition of presenting third-party independent inspection certificate to honor the credit by the issuing bank (Nelson, 2000, p. 48).

Independent inspectors can provide a different range of services and certificates including the determination of the quality and quantity of goods, proof of loading the goods, the determination of components and packaging of goods, etc. Employing independent inspectors is costly based on the bargaining power of parties; however, it would be possible to share costs of inspection on the basis of negotiations.

\subsubsection{Acceptance of time drafts instead of sight drafts}

While in presenting sight drafts, the beneficiary will be paid immediately, in the operation of time drafts there a gap between presentations of draft by the beneficiary and honoring the credit by the issuing or the confirming bank. Application of a sight draft will make the inspection of goods by the buyer impossible and creates a chance of fraudulent conduct by the beneficiary. Therefore, in the operation of documentary letters of credit, applicants are advised to accept time drafts instead of sight drafts and, in this way, stop payment after discovering any possible fraud between the date of arrival of goods and the date of payment (Murray, 1993, p. 509). Another option is to include a provision 
in LC that permits honoring or complying the presentation to the beneficiary in a certain number of days after the presentation in order to provide necessary time for the applicant to verify the intended facts (Ying, 2003, pp. 46, 48). This way, the applicant will have a possibility to check the quality and quantity of delivered goods and apply for injunction in case of any unconformity with the underlying contract.

\subsubsection{Checking the position and capacity of the contractual vehicle}

The buyer is advised to insert provisions regarding the name of the contracted vehicle and date of shipment in the underlying contract (Xiaorong \& Ruiping, 2005). By agreeing to insert such clauses in the underlying contract, the applicant will have the chance to use databases such as the Lloyd's List Intelligence in order to confirm the location of the ship, its availability, its capacity and the possible date of arrival to the port of destination.

Additionally, the buyer should be aware of different terms of shipment and allocation of risks and liabilities to each partner accordingly. Extensive knowledge of trade and shipping terms can be a huge advantage for the buyer. For example, while preparing the contract of sales, buyers are recommended to use FOB terms instead of CIF terms in order to have maximum control over the shipped consignment (Ruiting \& Yunqing, 2005, p. 218).

\subsubsection{Confirming the authenticity of a bill of lading}

It is customary for buyers to ask a copy of the bill of lading and other documents of title to be emailed by the beneficiary before their presentation to the bank (Mukundan, 2008). Access to such documents will allow the buyer to determine the authenticity of them as well as their issuing body (Murray, 1993, p. 509).

The buyer is recommended to conduct a search on authenticity of the carrier's address and phone numbers besides legally recording the conversation with the issuer while confirming the authenticity of the bill of lading.

\subsubsection{Obliging the carrier to dispatch the bill of lading to the bank}

In some cases, the carrier provides the shipper (beneficiary of his agent) with a blank copy of the bill of lading long before the shipment is to take place. In such a condition, the risk of fraud will be very high as the beneficiary has access to a blank document of title and without any problem can fill it up and sign in the name of the carrier's agent (Murray, 1993, p. 509). As a result, in order to reduce the risk of fraud, the buyer is recommended to insert a provision in the contract of sales which conditions honoring the credit to the delivery of the bill 
of lading to the bank by the carrier. However, like all other preventive measures, delivery of a bill of lading to the bank by the carrier is not an absolute measure to prevent fraud, since no one has control over a situation in which the carrier and the beneficiary are both involved in a conspiracy of delivering a false bill of lading to the bank.

\subsubsection{Application of the 'sales on approval' clause}

Originally, the sales on approval clause has been included in international sales contracts for the purpose of examining the quality of delivered goods to the buyer in return to the payment to the seller. In such a condition, the seller will receive the payment after the buyer has approved the conformity of the delivered goods with the terms of the underlying contract. However, such a clause can also be used in order to prevent payment against nonexisting goods to fraudulent seller (Murray, 1993, p. 509). Therefore, the applicant buyers are recommended to insert a provision of sales on approval in their underlying contract of sales.

Despite all criticisms related to the inclusion of sales on approval clause in LC and the underlying contract against the autonomy principle of documentary letters of credit, the existence of such a provision (as an effective strategy) will provide the buyer with a legal basis to prevent honoring the presentation of fraudulent beneficiary by the bank and prohibit the bank from effectuating the payment.

The decision of the UK court in the case of Sirius International Insurance Corp $v$ FAI General Insurance Co Ltd. [2003] was in favor of inserting the sales on approval clause into the underlying sales contract. Jacob J of the court of first instance decided that the principle of autonomy will not cover the condition in which the beneficiary has expressly agreed in the underlying contract that he cannot draw down the amount of LC without agreement of applicant. The decision was confirmed by the Court of Appeal.

\subsubsection{Obtaining export credit insurance}

Buyers may apply for export credit insurance which is provided by the government and private institutions as well as obtain an insurance policy from insurance companies in order to mitigate the risk of fraud by beneficiary in an LC transaction. Insurance is considered as one of the most significant tools used in practice of risk management by shifting risks from the buyer to the insurance company (Young \& Tippins, 2001). Unfortunately, many insurance companies do not offer suitable insurance policies against fraud risk in LC transaction. Insurance companies either do not insure the LC fraud or insure it with very 
high premiums. Some insurance companies require a chain of transactions to be insured instead of one single transaction that will impose significant costs on the LC applicant.

By supporting importer and exporter at the same time, expert credit insurance plays an important role in facilitation of international trade. Export credit insurance services are provided by different institutions in different countries while they generally cover import, export and foreign investment risks. According to Van Houtte (2002), the main areas of risk coverage by export credit insurance include three categories: (1) Commercial and business risk: insolvency of the buyer, unwillingness of the buyer to pay and failure to perform the contract adequately; (2) political and country risk; and (3) financial and currency risks.

Fraud risk in a LC transaction can be categorized under a failure to perform the contract if the payment for nonexistent goods is the seller's failure to fulfill the contract of sales. Therefore, depending on the terms and conditions of export credit insurance, coverage will be provided for such failure.

\subsubsection{Requiring the electronic submission of conforming documents}

The process of documentary letter of credit transaction is overwhelmed with extreme amount of paperwork which is not only time-consuming but also inefficient and vulnerable to fraud (Christensen, 2003, p. 3). In order to solve this problem, the BOLERO project was introduced in 1999 (Islam \& Ahamed, 2008). BOLERO is a secure cross-industry platform for transfer of information which is owned by the SWIFT and TT Club (Insurer of ship-owners, terminal operators, freight forwarders and port authorities)(Godier, 2000, p. 1). The main idea behind the introduction of the BOLERO is reducing paperwork, vulnerability to fraud and secure delivery of documents of trade in electronic format. Legal framework of electronic presentation of documents in $\mathrm{LC}$ operation has been introduced by the ICC as eUCP. BOLERO can be an efficient and effective solution to manage the risk of fraud for all parties of international LC transaction (bank, buyer and seller) despite insignificant cost of using it. Buyers can require electronic presentation of documents which will reduce the risk of fraud due to higher security of digital signatures and use of other cryptographic techniques (Collyer, 2003, p. 1). 


\subsection{Preventive measures for the beneficiary}

\subsubsection{Doing business with reliable buyers}

Trading with a reliable business partner is considered the most useful fraud prevention measure for either party in international transaction of documentary letters of credit. A beneficiary may access information about the financial standing and business history of new buyers from local banks and professional institutions which provide information on business credibility (Cheng \& Xiao, 2008). Such information will be of utmost importance when the buying business partner is an intermediary. Therefore, doing research on its financial standing and business history becomes vital in fraud risk management.

\subsubsection{Conducting a thorough check on details of LC before accepting its terms}

After receiving the letter of credit, a beneficiary should check all the details of LC clauses with due care. Also, the beneficiary needs to allocate enough time to apply for necessary amendments which prevent difficulties in preparation of confirming documents. In checking the LC clauses, two main issues should be considered by the beneficiary. First of all, the validity of the letter of credit should be approved. Validity check of an LC includes terms for effectuating payment, credibility of the issuing bank and proper period of validity. Later on, the beneficiary or his employees should conduct due checks on conformity of LC clauses with underlying international sales contract (Hu, 2007).

In case of defining any discrepancy or soft clauses in LC, the beneficiary should inform the applicant immediately and require amendments. Consecutively, the deadline for amendments should be clarified by the seller as well as any new required guarantee and extension of LCs expiry date due to delays caused as a result of required amendment (Cheng, 2007). The beneficiary has the right to claim for damages for breach of underlying contract in case of the applicant's inability to obtain LC with inclusion of required amendments or time or refusal to implement amendments and extend the expiry date.

\subsubsection{Prudence in drafting sales contracts}

Underlying international sales contract serves as a foundation of operation of the letter of credit. Therefore, it is recommended that the beneficiary pay enough attention in drafting international sales contract with a particular emphasis on the clarity of required document (Tao, 2009). Such required documents can be bill of lading, commercial invoice, insurance policy, certificate of origin, inspection certificate and any other required document. Additionally, scenario planning and 
defining contingency plans in case of raising problems in underlying contract is recommended as a technique used by the beneficiary in order to reduce the risk of fraud.

\subsubsection{Promoting inter-organizational communication and cooperation with banks}

LC operation is risky and the beneficiary should be confident that all internal units are aware of existing risks. Such confidence will be achieved only by establishing effective internal communication among different units. It is also advised to the beneficiary to establish cooperative relations with the advising bank. The beneficiary can find out about the "credibility of issuing bank, avoid soft clauses in LC and transfer the risk of fraud in documentary letters of credit" (Ying \& Zhiyong, 2003, pp. 44) through cooperation with the advising bank.

\subsubsection{Defining a criteria to deal with soft clauses}

Since there is no global criteria for the classification of LC soft clauses and such clauses are numerous in different stages of LC operation, the beneficiary should manage the risk of soft clauses by defining effective criteria for identification of them in international LC transaction. Availability of such criteria will help the beneficiary to recognize the existence of soft clause in documentary letter of credit, defining its type and recognizing the way to mitigate its risk (Zhang, 2011). Beneficiary sellers are strongly recommended to solve the problem of LC soft clauses before dispatching goods to applicants.

\section{Responding to $L C$ fraud}

Even the most advanced preventive measures might fail. Therefore, any party involved in an international LC transaction should have a proper and systematic response system in place to react promptly in case of facing documentary letter of credit fraud (Zhang, 2012). Such systematic response should include different steps including: identification and search for suspected signals, and determining the reality of the situation via approach to foreign banks, shipping and cargo agents, brokers, maritime organizations such as the Lloyd's List, etc. The next step can be investigating facts in the country of the fraudster, taking legal action against the fraudster, applying for interim injunction in order to freeze the fraudster's financial assets (Yuqun \& Zhenying, 1999, p. 312). 


\title{
6. Conclusion
}

Fraud can impose significant costs on the enterprise. Therefore it is recommended to include fraud risk in the core of the enterprise risk management (ERM) program. Proper fraud risk management contains effective preventive and responsive measures which also apply to fraud risk management programs applied to documentary letters of credit. There are many reasons for the vulnerability of international LC transactions to fraud risk, including the banks' sole reliance on documents, the geographical distance between the applicant and the beneficiary, lack of globally accepted legal framework to prevent and respond to risk of fraud in LC transaction. Therefore, all parties involved in operation of documentary letters of credit are required to implement necessary preventive and responsive measures in order to mitigate the risk of LC fraud. In addition to analyzing theoretical aspects of fraud in documentary letters of credit, this paper tried to explore different methods for mitigating fraud risk by taking a look at various preventive methods which can be applied by applicants, beneficiaries and banks to minimize the occurrence of fraud as well as the different steps that an enterprise should take while being defrauded.

\begin{abstract}
Hamed Alavi, MBA, LLM is currently lecturer of international trade and international trade law at Tallinn University of Technology, Estonia. He started his career with UNHCR and IOM in Iran and later moved to academia in 2008 after starting his collaboration with Caucasus University in Georgia. He has extensive experience in research and teaching in different European and non-European universities.
\end{abstract}

\section{References}

AICPA (2009), The Basics of Fraud Risk Management, Business Brief, vo1s. 1 \& 4. Retrieved from http://fmcertre.aicpa.org/NR/rdonlyres/33E55856-1A414D02-BBA8CD5B51724E4C/0/Fraud_Risk_Management_Business_Brief.pdf [accessed 8 Aug 2015]

Banco Santander SA v Banque Paribas [2000] EWCA Civ 57, 1 All E.R. (Comm.) 776. Banco Santander S.A. v Bayfern Ltd. [1999], EWHC 284 (Comm), WL 250019, Q.B.

Buckley, R. P. \& Gao, X. (2002), The development of the fraud rule in letter of credit law: the journey so far and the road ahead,' University of Pennsylvania Journal of International Law, vol. 23, no. 4, pp. 663-712. 
Carey, A \& Turnbull, N. (2001), 'The boardroom imperative on internal control,' in J. Pickford (ed.) Mastering Risk - Volume 1: Concepts, Edinburgh: Pearson Education Ltd., pp. 11-14.

Cheng, S. L. \& Xiao, X. (2008), 'Discussion on L/C fraud,'Pioneering with Science \& Technology Monthly, no. 8, pp. 131-132.

Cheng, Z. (2007), 'The risk and its prevention in international letter of credit transactions by exporters,' Science and Educational Innovation, no. 6(March), pp. 220-221.

Christensen, K. (2003), 'Will the UCP help electronic trade grow up?' Documentary Credits Insight, vol. 9, no. 1(Jan-Mar).

Collyer, G. (2003), 'Will online letters of credit rule?' Trade Finance London, September.

Crockford, N. (1980), An Introduction to Risk Management, Cambridge: WoodheadFaulkner Ltd.

Crouch, E. A. C. \& Wison, R. (1982), Risk/Benefit Analysis, Cambridge \& Massachusetts: Ballinger Publishing Company.

Demir-Araz, Y. (2002), 'International trade, maritime fraud and documentary credits,' Journal of International Trade Law \& Regulation, vol. 8, no. 4, pp. 128-133.

Ellen, E. (1998), 'Complex L/C frauds put banks at risk,' DCI (ICC), vol. 4, no. 1(Winter).

Godier, K. (2000), 'Electronic trading: new systems emerge,' Documentary Credits Insight, vol. 6, no. 2(Spring).

- (2001), 'Trends show a declining reliance on letters of credit,'Documentary Credits Insight, vol. 7, no. 3(July-September)

Harfield, H. (1974), Bank Credits and Acceptances, 5th ed., New York: Ronald Press Company.

Harvard Law Review (1980), “Fraud in the Transaction': Enjoining Letters of Credit during the Iranian Revolution”, vol. 93, no. 5, pp. 992-1015.

Hertz, D. B. \& Howard, T. (1983), Risk Analysis and Its Applications, New York: John Wiley \& Sons.

Hu, Y. (2007), 'Soft clause of L/C and risk prevention,' Market Modernisation, vol. 512, no. 2 .

ICC (2002), Trade Finance Fraud -Understanding the Threats and Reducing the Risk, A Special Report prepared by the ICC International Maritime Bureau (Paris).

ICC Commercial Crime Services (2002), Preventing Financial Instrument Fraud - The Money Launderer's Tool, no. 648, A Special Report prepared by ICC Commercial Crime Bureau, Essex: ICC Publishing.

Islam, S. \& Ahamed, S. (2008), 'Preventing letter of credit fraud,' DIU Journal of Business and Economics, vol. 3, no. 2.

Liu, Z. (2006), 'Risk and prevention of bank under L/C', Market Modernisation, vol. 459 , no. 2 .

Monahan, G. (2008), Enterprise Risk Management: A Methodology for Achieving Strategic Objectives, vol. 20, New York: John Wiley \& Sons. 
Mukundan, P. (2008), 'Fraud with L/Cs - latest modi operandi,' Speech of the Executive Director of the ICC Commercial Crime Services and material at the 2nd Annual International Conference on Letters of Credit organized by ICC Austria, Vienna, 29 May, 2008.

- (2009), 'Trade finance frauds,' Speech and material at the 3rd Annual Conference on Letters of Credit, organized by ICC Austria, Vienna, 14 May, 2009.

Murray, D. E. (1993), 'Letters of credit and forged and altered documents: some deterrent suggestions,' Commercial Law Journal, vol. 98, no. 4, pp. 504-509.

Nelson, C. A. (2000), Import Export: How to Get Started in International Trade, New York: McGraw-Hill.

Ruiting, W. \& Yunqing, D. (2005), 'Study on countermeasures of L/C fraud,' Market Modernisation, vol. 217, no. 2.

Sirius International Insurance Corp v FAI General Insurance Co Ltd. [2003] EWCA Civ 470 [2003] 1 WLR 2214.

Spencer Pickett, K. H. (2006), Enterprise Risk Management: A Manager's Journey, Hoboken, NJ: John Wiley \& Sons, Inc.

Tao, H. (2009), 'L/C fraud and preventive measures in international trade', Modern Business, no. 11, pp. 89-91.

Todd, P. (1996), “Can banks protect themselves against buyers' frauds?” Documentary Credits Insight (ICC), vol. 2, no. 4 (Autumn), pp. 15-16.

UNCTAD (2003), A Primer on New Techniques Used by the Sophisticated Financial Fraudsters with Special Reference to Commodity Market Instruments, UNCTAD/ DITC/COM/39, 7 March. Retrieved from http://www.unctad.org/en/docs/ ditccom39_en.pdf [accessed 8 Aug 2015]

- (2009), Trade and Development Report 2009, UNCTAD/TDR/2009, Geneva: UNCTAD.

Van Houtte, H. (2002), The Law of International Trade, 2nd ed., London: Sweet \& Maxwell.

Xiaorong, G. \& Ruiping, N., eds (2005), Research on Internationalization of Punitive Regulations on Financial Crimes, Peking: Law Press China.

Xinqing, Y. (2007), 'L/C Fraud and Prevention in International Trade', Group Economy, vol. 227 , no. 2 .

Ying, X. \& Zhiyong, Z. (2003), 'Discussion on L/C fraud and its precautions,' International Economics and Trade Research, no. 5, pp. 41-44.

Ying, Z. (2003), 'Documentary L/C fraud: dilemma in prevention,' The Economist, no. 5, pp. 46-48.

Young, P. C. \& Tippins, S. C. (2001), Managing Business Risk: An Organization-Wide Approach, New York: AMACOM.

Yuqun, Y. \& Zhenying, C. (1999), Shipping Fraud and Legal Countermeasures, Peking: People's Court Publisher. 
Zhang, Y. (2011), 'Can soft clauses in letter of credit transactions be considered letter of credit fraud in China?' Nordic Journal of Commercial Law, no. 1, pp. 1-20. (2012), 'Documentary letter of credit fraud risk management,' Journal of Financial Crime, vol. 19, no. 4, pp. 343-354. http://dx.doi.org/10.1108/13590791211266340 